\title{
How do Spanish and English Languages Determine Young Afro-Caribbean Descendants' Identity?
}

\author{
Grettel Vargas JimÉnez \\ Escuela de Lenguas Moderna, Sede Rodrigo Facio \\ Recinto de Paraíso, Sede del Atlántico \\ Universidad de Costa Rica
}

\begin{abstract}
Resumen
Considerando la diversidad lingüística que experimenta la población afrodescendiente de la provincia de Limón, esta investigación se basa en un enfoque cualitativo, el cual analiza y compara, desde una perspectiva etnográfica, a un grupo de diecinueve jóvenes estudiantes afrodescendientes del Colegio San Marcos, en Limón, con un grupo de igual número de adultos afrocaribeños del centro de Limón y sus alrededores, con el propósito de establecer comparaciones y conclusiones acerca de cómo se definen ellos: como nativos hablantes del idioma español, como nativos hablantes del idioma inglés, cómo nativos hablantes del criollo limonense o como multilingües, y el rol que desempeñan estos lenguajes en la formación de su identidad. Asimismo, este diseño etnográfico trata de describir y evaluar las percepciones, comportamientos, conocimientos y experiencias de ambos grupos en relación con el lenguaje en diversos contextos y situaciones.
\end{abstract}

Palabras claves: identidad, español, inglés, criollo limonense, afrocaribeño, escuela tradicional de inglés, estereotipos

\begin{abstract}
Considering the linguistic diversity Afro descendants experience in Limón province, this research project is focused on a qualitative approach and basically it portrays an ethnographic perspective about nineteen (19) young Afro descendant students at Saint Mark's high school in downtown Limón, and the same number of older Afro-Caribbeans in downtown Limón and surroundings in order to establish comparisons and draw conclusions in regards to how they define themselves: as native
\end{abstract}

Recepción: 01-02-15 Aceptación: 29-06-16 
speakers of Spanish, as native speakers of English, as native speakers of Limón Creole, or as multilinguals, and the role of this badge of identification in the process of construction of their identity. Likewise, this ethnographic design tries to describe and analyze the ideas, beliefs, behaviors, knowledge and experiences of both Afro-Caribbean groups in relation to language and interaction in different contexts and situations.

Key Words: identity, Spanish, English, Limón Creole, Afro-Caribbeans, traditional English school, stereotypes

\section{Introduction}

$\mathrm{I}$ ndeed the arrival of African slaves to the American continent during the XVII and XVIII centuries contributed to improve the economy of many countries ruled by a white dominant population. In spite of their contributions, Blacks lived in bad conditions. As slaves they were considered "merchandise," many of them were sold out in streets, hardboards and parks including men, women and even children.

More than one hundred years later, when countries obtained independence from Europe, slavery was forbidden and abolished in most of the American continent. Nevertheless, African descendants have continued to struggle against segregation, social inequality and discrimination even today in the XXI century.

Afterwards, at the end of the XIX century, as a result of increasing of coffee exports to Europe, the Costa Rican government started the construction of a railroad from the Atlantic coast to the Central Valley. Sawyers and Perry describe that historical episode:

A second African descendants' immigration took place in 1871 due to the perceived urgency of the construction work to build a railway from Limón to San José, foreign laborers were brought in. Most of the new migrant workers were Afro-Caribbean. While many came directly from the islands, especially Jamaica. (1996, 24)

In addition, these new labor force brought with them their culture, food, language and religion. However, these Jamaican immigrants were not interested in learning Spanish because they thought that they were going back to Jamaica, "they didn't want to speak Spanish because they had in mind to return to Jamaica, so why learn Spanish?" (Duncan, Quince Personal Interview, August 2011). Nevertheless, the Jamaican descendants who were born in Costa Rica were not allowed to speak English in schools and in an effort to match with the Hispanic Costa Rican identity of Spanish speakers, little by little, new generations of Afro-Limonese have become monolingual. However, older generations still speak Standard English (SE) or a dialectical variation of it, mainly at church during religious ceremonies and during official celebrations. They also prefer to speak Limón Creole (LC) or Limonese Creole (LC) with their friends on the street and at home. In spite of all the efforts several Costa Rican's governments have made to eradicate English, mainly LC in Limón, Afro-Caribbeans still use their ancestral language as a connection with their Afro-Jamaican origins and cultural identity. 
In brief, looking at Limón as multicultural and multilingual province and particularly the case of its Afro-Caribbean residents, the aim of this research project is to explore how Spanish and English languages influence young Afro descendants' identity by comparing nineteen students at Saint Mark's high school at downtown Limón and the same number of adults from different places of Limón.

\section{The Problem and its Importance}

Concerning that situation, different Costa Rican governments have taken advantage of language particularly Spanish, the official language, as a way of domination in the past. Similarly, the educational system has contributed to regulate population into the national culture and prevailing a social stratification system. In like manner, there are different kinds of manifestations against Black population in Costa Rica such as government lack of investment and the media's influence on racism.

Undeniably, there are similar studies about Afro-Costa Rican population. For example, Quince Duncan and Carlos Meléndez in El Negro en Costa Rica explore different kinds of discrimination Blacks have suffered through the years in Costa Rica, in which Afro-Caribbeans have struggled with racism, social and economic inequality, cultural and linguistic imposition as well as isolation and indifference by Costa Rican governments.

Similarly, Trevor W. Purcell in $B a$ nana Fallout refers to the inequality of language in social practice in Costa Rica in regards to the Black experience. In addition, in September 2010,
UNICEF (Fondo de las Naciones Unidas para la Infancia) and IDESPO (Instituto de Estudios de Población, Universidad Nacional), published a study in regards to Costa Rican's perception about Afro-descendant population in which issues like ethnicity, racism, discrimination, human rights, identity's perceptions and political and ethical implications are evaluated in order to determine the extent to which this population is integrated to the social scheme in Costa Rica. (Percepciones de los Costarricenses sobre la Población Afro Descendiente, 2010: índice iii).

Basically, this research project is a response to a personal reflection in downtown Limón during May, June and July, 2010. This experience took place in a lecture conducted by professor George Watts who is an Afro-descendant, who has lived in Limón for 65 years. He has worked for the Ministry of Education (M.E.P.) in Costa Rica for more than forty years. Even though he retired several years ago, he continues doing what he loves most: teaching. Currently, he works at Universidad Latina in downtown Limón. During a lecture, he explained to a group of students that although he was born in Costa Rica, he considers himself Jamaican since he has been "rejected" and discriminated his whole life, especially by people from San José and for that reason he prefers to speak English and not Spanish. He concluded his lecture by saying that Blacks are victims of racism and segregation and for that reason, Limón is the poorest province in Costa Rica.

Besides, a person visiting Limón can appreciate how poverty, unemployment and violence have increased everyday, particularly in some neighborhoods such as Limoncito, Cieneguita, Moín, 
and Liverpool. However, not all the population lives this situation. Young students at St. Mark's high school consider themselves to be quiet, tender, friendly, and happy people, but they know others' perceive them as violent and dangerous. Certainly, this label of being "others" is based on negative stereotypes that are amplified by media in which even the whole province is perceived in this way.

As mentioned before, one of the main goals of this investigation goes along to creating awareness about linguistic diversity Afro-descendants experience by comparing a group of young Afro-Costa Ricans with a group of older Afro - Caribbeans (whose ages range from 35 to 85 years old). This will be done in order to establish comparisons and draw conclusions in regards to how they define themselves: as native speakers of English, as native speakers of Limón Creole English, as native speakers of Spanish or as multilinguals and the role of this badge of identification in the process of construction of their identity.

This project is an ethnographic research in which it is important to understand that ethnography is "the work of describing a culture and its goal is to understand another way of life from the natives' point of view. In addition, it is a useful tool for understanding how other people see their experience emphasizing the fact, however, that rather than studying people, enthnography means learning from people" (http://www.ncrel.org.htm $\mathrm{np})$. Likewise, this is a particularistic ethnography, that is "the application of a holistic methodology to particular groups or social units" (Hernández Sampiere etal:2006,699). It is important to point out that the population who is going to be observed and analyzed is all Afro Caribbean descendents who were born in Limón province.

\section{Theoretical and Practical Background}

Basically, "there are three main languages spoken in Limón province: Spanish (the official language), Standard English (used in the churches and schools) and Limón Creole (LC) a changed form of Jamaican Creole" (Purcell: 1993, 106). Certainly, the AfroCaribbean residents in Limón province contributed not only to improve Costa Rica's economy since also they helped to build a multilingual, multicultural, and multiethnic society in Costa Rica.

Indeed, in the multicultural and multilingual environment of Limón, particularly in the use of Spanish, Standard English and Limonese Creole, contribute to form a diglossic bilingual condition in the population who uses these languages. According to Phillip Riley in Language, Culture, and Identity:

Diglossia is a form of standardized societal bilingualism, characterized by the complementary distribution of the functions of two language varieties. There is a relation of superiority/inferiority between a high variety $(\mathrm{H})$ and a low variety (L) in which $\mathrm{H}$ is more prestigious, standardized and written, official and formal, it is a symbol of national and religious identity. $\mathrm{L}$ is local, acquired informally and expresses social solidarity. $(2007,58)$

Thus, the evidence suggests that in this diglossic relation Spanish and 
Standard English represent the high variety $(\mathrm{H})$ whereas the Limonese Creole corresponds to the low variety (L). That is "the Standard English" (SE) is used in formal situations such as meetings, religious ceremonies, at school and for talking with our superiors, especially our parents or grandparents" (Duncan, Quince, Identidades, June 2010). On the other hand, Limón Creole (LC) is used in informal situations "that is the language we use in the street with our friends, with our buddies" (Duncan, Quince Identidades, June 2010). There are a lot of negative stereotypes against Limón Creole for considering it bad English or a bad language. In fact, mestizo Costa Ricans refer to it as broken English, banana English, mekaytelyuw or "patúa (patois) that is actually a mixture between French and Spanish" (Senior: 2011, 26) mainly because of their lack of understanding in relation to the use of English language.

This variety of Creole that is spoken in Limón by Afro-Caribbeans is a variety of the Creole spoken in Jamaica. In fact, some Costa Rican linguists conclude that:

The LC is a symbol of identity for Afro Caribbeans, you know? The Afro Caribbeans that have been raised speaking English in Providence, St. Catherine, it is the same LC. It is the same spoken in Belize, in Bluefields, in Bocas del Toro, etc. It is the same one spoken in Jamaica. So, that sign of identity is very important (Pochet, Lina, Identidades, June 2010).

In addition, Anita Herzfeld thinks that "language, as a symbol of group identity, it is one of the major forces for the preservation of the speech of subordinate linguistic groups. Illustrating the use Afro-Costa Rican speakers of Limonese Creole make of their language" (2004, 2). Then, AfroCaribbeans secured their cultural and linguistic heritage through their traditions, religion and mainly through their Traditional English Schools (TES) whose curriculum was British. For this reason, they decided to continue with their English education by bringing teachers from Jamaica and in some cases from England. Nevertheless, at that time and in the context of a Hispanic culture, considering Spanish as the official language, the Costa Rican government undertook serious efforts to acculturate the minorities of Creole languages to the Spanishspeaking culture. Thus, as a result of these policies of integration, successful literacy campaigns took place and the use of English was forbidden in schools in Limón.

Indeed, the Costa Rica's Ministry of Public Education (MEP) fostered a strong Spanish language instruction for all Costa Rican citizens minimizing local languages from Afro-Caribbean to the local Indian Costa Rican ones. Thus, "the government decided from the 1950's to the 1960's to forbid the use of English in Limón by closing the traditional English schools because as Costa Rican citizens, the Black limonese must speak Spanish" (Duncan, Quince interviewed by Grettel Vargas, August 12, 2011). The idea in that time was to acculturate and "integrate" minority groups of Creole languages to the Spanish-speaking culture. Then, the use of English was forbidden in schools in Limón advocating the use of Spanish as an official language. 
Thus, Afro-Caribbean children were punished and humiliated because of their language and also they were also humiliated because of their culture: "Since you eat ñame, you are not Costa Rican! -So, what happened then, we ate ñame no more, because we wanted to be Costa Rican!" (Grant, Lety, Identidades, June 2010). Hence, the imposition of the Spanish School (SS) affected Afro-Limonese children linguistically, culturally and mainly psychologically affecting their self esteem: children learned that their mother tongue English lacked prestige and Spanish, as the Costa Rican official language, was a language of high prestige. Therefore, Afro Caribbean children learned that the English from Limón was banana English, broken English, Makaytelyuw, etc. They also learned that they did not speak Spanish properly. Thus, English was suppressed in Limón by the Costa Rican government and to make matters worse, Afro-Caribbean pupils were removed from their identity since they also understood that the difference between English and Spanish was racial too.

As Lorein Powell states: "The public school system aims at homogenizing ethnic groups into the national culture and dominant social stratification scheme in which the violence exerted by the state upon the traditional English schools of Limón appears to have been grounded in racism from the very beginning" (Powell: 2002,151). So far, there is no evidence or at least any possible good intention neither by governmental authorities for promoting Afro-Caribbean values, nor by the Costa Rican educational system.

Indeed, "considering that the country's official language is Spanish and that the Costa Rican identity is characterized by Spanish speakers, Roman Catholics and "whites"; then, the Afro-Caribbean does not fit in this national image as an English speaker who is Protestant and Black" (Stocker: 2004, np). Thus, the Costa Rican government decided from the 1950's to the 1960's to forbid the use of English in Limón by closing the traditional English schools because as Costa Rican citizens they must speak Spanish.

On the other hand, there are connections that are identified between power and language, and they are related to identity. As Isaacs affirms: “ ... first learned language is, to begin with, the mother's tongue, with all that conveys and contributes to the forming of the self and the development of the individual personality. Each of the manifold uses of language has its special importance for the discovery of identify" (1998, 94). In addition, language shapes and forms our personality and for that reason, language is fundamental to discover our identity. From this stand point, it is important to discern the role of Spanish, English and Limón Creole English as a mother tongue in the formation of young Afro-Caribbean's identity.

In spite of this situation, Afro-Costa Ricans were able to keep their traditions and language as a way to preserve their identity from their ancestors. One can notice in downtown Limón that in spite of the imposition of Spanish language (and culture), people still speak standard English and Limón Creole which is very common among adults and seniors.

Equally important is the role parents play in their children identity formation process by preserving language, culture, and communication. In the case of Limón Afro-Caribbean young people, it is important to understand what kind 
of efforts older generations have made in order to transmit their values and identity to new generations.

\section{Qualitative Research Design}

This investigation is focused on a qualitative approach that is an ethnographic study of the Afro Caribbean population in downtown Limón and nearby. According to Le Compte and Preissle, "ethnographic and qualitative research often is equated with hermeneutic or interpretive research. In this way, hermeneutics is concerned with ways to explain, translate and interpret perceived reality $(2003,31)$. Likewise, this ethnographic design tries to describe and analyze the ideas, beliefs, behaviors, knowledge and experiences of four specific Afro-Caribbean groups in relation to language and interaction in different contexts and situations.

Further, in order to gather information, this ethnography study includes several data collection instruments such as open ended questions, closed question structured interviews, four tape recorded interviews, non participant and participant observations, photoethnography, videos, artifacts collection, and a selection of 10 random participants in an informal environment. Finally, it is essential to mention that all the information collected provides validity to this qualitative research since all the data gathered came directly from the informants.

\section{Research Setting and Population}

In order to delimit the factors involved in the construction of identity among Afro-Caribbean youth, the information required for the execution of this project was obtained from a total of nineteen students from tenth and eleventh grades at Saint Mark's high school as well as the same number of Afro-Limonese adults in downtown Limón and nearby places.

In regards to the students, the majority of these learners (boys and girls) are from downtown Limón or its surroundings. Their ages range between fifteen and eighteen years old. Saint Mark's high school is a private school (kinder garden, primary and secondary high school) in which most of its learners are Afro-Caribbean. There is a small percentage of Chinese descendants as well as mestizos. The number of learners per group is around fifteen to twenty students in every classroom. The school has its own methodologies and rules, but the educators follow the evaluation format of MEP.

In relation to the Afro-Caribbean adults, they are from different neighborhoods and professions and some of them are already retired. Their ages ranged between nineteen to eighty four years old. Among the adults that were observed these were secretaries, teachers, janitors, priests, employees in markets and radio stations, nurses in hospitals, employees in supermarkets, waiters in restaurants, taxi drivers, etc. Some of them were interviewed at St. Mark's high school, others in Limón Central Market and surroundings, on small cafeterias (sodas), at Methodist church, at Radio Casino, on the street, at the Tony Facio Hospital, at Vargas Park, on Roosevelt neighborhood (best known as Jamaica Town) and at Pueblo Nuevo neighborhood. 


\section{Presentations and Analysis of Results}

As it was mentioned before, language is one of the main features that best defines peoples' identities. Through language civilizations transmit knowledge, customs and history that characterize cultures. Instead, it is important to remember that also through a tongue, linguistic and cultural barriers have been established everywhere by dominant societies as a way of imposing and creating subordinated groups. However, the preservation of a language depends on the efforts communities do in order to perpetuate their tongue to new generations. As Anita Herzfeld demonstrates:

Thus, the Limonese Creole speakers' underlying sense of dignity, and a feeling of self-worth derived from their ancestral roots--apparent today in a revival of their folklore-may deter the decline in language usage. If, in light of their socio-historical background, the groups value their identity. $(2004,11)$

Consequently, if the languages of minority populations begin to gain official recognition, there may eventually result in recognition, not only of their human dignity and identity, but also of the value of multiculturalism.

As a consequence, the main purpose of this investigation is to portray a vision of how young and adult AfroCosta Ricans perceive the influence of Spanish and English languages on their process of identity formation. Thus, within the broader objective pointed out above, this research pretends to accomplish the following specific objectives: to explore the aspects of the native culture that enhance Afro Caribbean customs, to analyze the students' perceptions in relation to language and identity in Limón, to identify the type of language students use at home and at school, to analyze the students' awareness in relation to Afro Caribbean identity, to understand the Afro Caribbeans' opinions about language diversity in Limón and to determine the informants' judgment about the use of the Limón Creole.

During the interviews, students and adults were asked about how they relate language to identity. That is, in the open ended structured interview question No. 16: Como afrocaribeño, ¿En qué forma relaciona usted idioma con identidad?

\section{Exhibit $\mathrm{N}^{\circ} 1$ \\ Relation between Language and Identity}

Frequency Percentage

$\begin{aligned} & \text { Part of identity, } \\ & \text { culture and } \\ & \text { history }\end{aligned}$

English is part

$3 \quad 16 \%$ of our culture

There is no

$1 \quad 5 \%$

relation

\begin{tabular}{lll} 
No answer & 4 & $20 \%$ \\
\hline
\end{tabular}

Source: Students' Structured Interview--Open Ended Questions, September 2011.

Among the 19 students interviewed, $59 \%$ which represents 11 learners, said that language is part of identity culture and history, 16\% (3 pupils) mentioned 
that English is part of our culture, one student (5\%) expressed that there is no relation and 4 learners (20\%) did not provide any answer.

In relation to the adults, $32 \%$ that means 6 out of the 19 adults interviewed, expressed that language is part of their identity, 20\% (4 adults) agreed that it is part of culture and history, another 4\% (4 informants) said that English and Spanish are part of our Afro-Caribbean culture whereas 23\% (5 participants) mentioned emphatically that only English is part of Afro Caribbean culture. Finally, one person (5\%) did not provide any answer.

Exhibit N. ${ }^{\circ} 2$

Relation between Language and Identity

\begin{tabular}{lcc}
\hline & Frequency & Percentage \\
\hline $\begin{array}{l}\text { Part of identity } \\
\text { Part of culture }\end{array}$ & 6 & $32 \%$ \\
$\begin{array}{l}\text { English and } \\
\text { Spanish are part } \\
\text { of our culture }\end{array}$ & 4 & $20 \%$ \\
$\begin{array}{l}\text { Only English is } \\
\text { part of our culture }\end{array}$ & 5 & $23 \%$ \\
\hline \begin{tabular}{l} 
No answer \\
\hline
\end{tabular} & $\mathbf{1}$ & $\mathbf{5 \%}$ \\
\hline
\end{tabular}

Source: Adults' Structured Interview--Open Ended Questions, September-October 2011.

In regards to the question: Are young Afro-Caribbean losing the use of Limonese Creole? 47\% students answered negatively, whereas 53\% affirmed that young generations are losing the use of Limón Creole.

\section{Exhibit $\mathrm{N}^{\circ} 3$ \\ Students' Perceptions about Limón Creole}

Are young Afro Caribbean losing the use of Limón Creole?

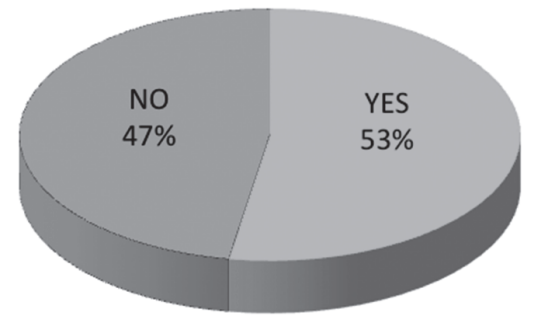

Source: Students' Structured Interview--Open Ended Questions, September 2011.

Among the answers that students gave to this question were that some young people are ashamed of $\mathrm{Lim}$ onese Creole because they consider to be bad English, others explained that their parents prefer to speak Spanish at home, some clarified that there were many young people who do not know how to speak LC or even they are not interested in learning it. In addition, there was one student who declared that younger Afro-Caribbeans are losing the use of $\mathrm{LC}$ because TES were closed in Limón. On the other hand, those who believed new generations keep Limón Creole judged that they listen to Limonese Creole everywhere and others said that some families maintain this language at home. 
Exhibit N. ${ }^{\circ} 4$

Adults' Perceptions about Limón Creole

Are young Afro Caribbean losing the use of Limonese English?

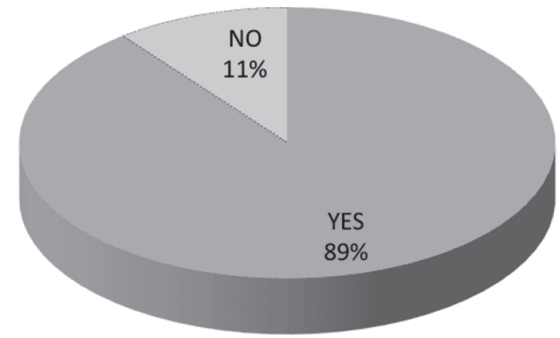

Source: Adults' Structured Interview--Open Ended Questions, September-October 2011.

Instead, $89 \%$ of adults affirmed that younger generations are not interested in learning Limón Creole because of the growing of racially mixed families in which white mestizo mothers speak only Spanish at home. Further, old bilingual generations are disappearing, also children are learning American English at school and traditional English schools do not exist anymore. However, $11 \%$ of the adults interviewed said that young AfroCaribbeans in Limón are not losing Limonese Creole because these children and teenagers attend to protestant churches in which people speak English.

In relation to the use of Spanish, as part of the Afro-Caribbean's identity, $58 \%$ students considered that Spanish is part of the Afro-Caribbean culture and identity since Limón Creole is mixed with Spanish. As teacher Sharon Foster remarks: "If the students are outside the school, they speak Spanish. In fact, Spanish is the predominant language in the classroom; but you have to be with them in class in order to make them to speak English (Foster, Sharon, interviewed by Grettel Vargas, November 1st, 2011).

\section{Exhibit $\mathrm{N}^{\circ} 5$ \\ Spanish as Part of Afro-Caribbean's Identity in Costa Rica}

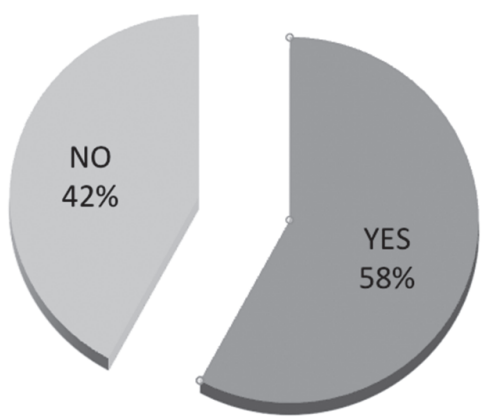

Source: Students' Structured Interview--Open Ended Questions, September 2011.

In like manner, all Afro-Caribbeans speak Spanish. Nevertheless, $42 \%$ of the learners believed that Spanish is not part of the Afro-Limonese culture because English is the language spoken by groups of Afro Caribbeans. Similarly, the pupils explained that Spanish is not related to the Afro-Caribbean culture and first generations of Jamaicans had to learn it for communicate with Costa Ricans in the past.

\section{Exhibit $\mathrm{N}^{\circ} 6$ \\ Spanish as Part of Afro-Caribbean's Identity in Costa Rica}

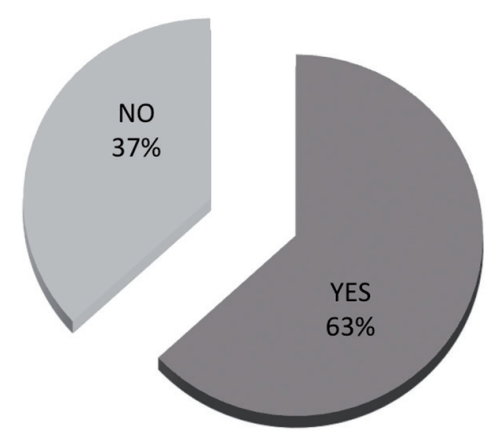

Source: Adults' Structured Interview--Open Ended Questions, September-October 2011. 
On the other hand, $63 \%$ of the Afro-Limonese adults interviewed affirmed that Spanish is part of the Afro-Caribbean's identity and culture because Spanish and English represent ethnic and linguistic diversity. Indeed, they expressed that they are identified with Spanish as Costa Rican citizens since Spanish is Costa Rica's official language. On the contrary, 37\% of them said that Spanish does not belong to the Afro-Caribbean identity since Spanish is the language of Spaniards and that it is the identity of Hispanic people. Likewise, one person clarified that since she is Costa Rican she speaks Spanish because it is the country's official language, but she feels she is losing her identity as Afro-descendent because her language is English as part of her ancestors' heritage.

Instead, to the question: Is there any relationship between the Afro-Caribbean culture and Limón Creole? all the students agreed that Limón Creole is part of the Afro Caribbean culture.

\section{Exhibit $\mathrm{N}^{\circ} 7$ \\ Limonese Creole as Part of Afro- Caribbean's Identity in Costa Rica}

Is there any relationship between the Afro-Caribbean Culture and Limón Creole?

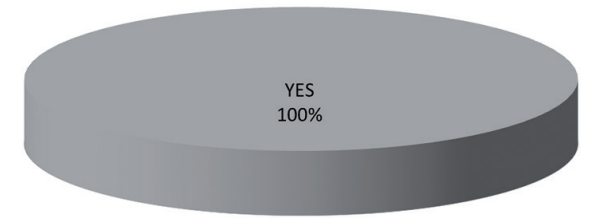

Source: Students' Structured Interview--Open Ended Questions, September 2011.

Among the reasons that supported their opinions, they described that this Creole is only spoken in Limón by the Afro-Caribbean population in Costa
Rica; therefore, it belongs to Afro-Costa Rican culture and identity. Lemonese Creole was the language Jamaicans spoke between them during the rail road's construction. Finally, they empathized that the Creole is the same language that people use for communication in other Caribbean countries and through this tongue people transmit customs, history, music, traditions and so on.

In contrast, $79 \%$ of the adult AfroCaribbeans interviewed said that Limón Creole is part of Afro-Caribbean culture because they consider that their culture without English would not be the same.

\section{Exhibit N ${ }^{\circ} 8$ \\ Limonese Creole as Part of Afro- Caribbean's Identity in Costa Rica}

Is there any relationship between the Afro Caribbean Culture and Limón Creole?

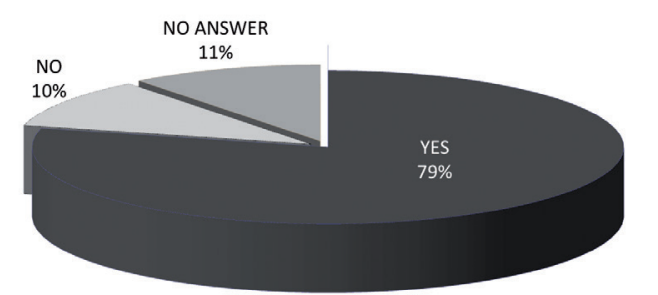

Source: Adults' Structured Interview--Open Ended Questions, September-October 2011.

Similarly, they agreed that traditions must be preserved through language and indeed Limonese Creole was the language of the first generations of Jamaicans who arrived to Limón. Naturally, 11\% of Afro-descendents believed that Afro Caribbean older generations used to speak more Limón Creole in the past, while $10 \%$ of other Afro-Limonese provided no answers to this question. 
Indeed, in relation to the question Is it important to preserve the Limón Creole? 90\% of the learners considered that it is important to preserve the Limón Creole since it is part of the AfroCaribbean identity.

\section{Exhibit $\mathrm{N}^{\circ} 9$ \\ Limonese Creole as Part of Afro- Caribbean's Identity in Costa Rica Is it important to preserve the Limón Creole?}

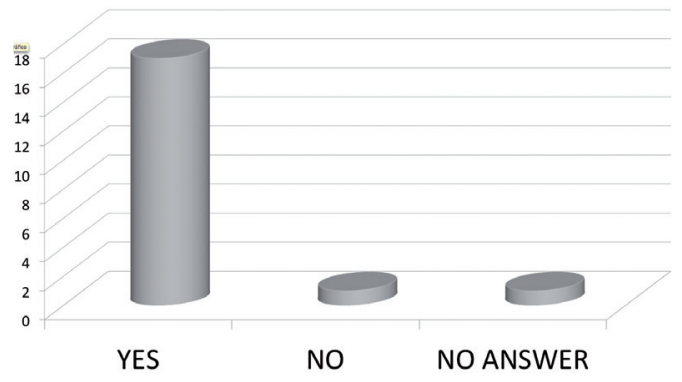

Source: Students' Structured Interview--Open Ended Questions, September 2011.

In like manner, Saint Mark's students believed that young generations of Afro-Caribbeans should learn Limón Creole at school and they should not be ashamed of speaking this language. In fact, learners considered that mestizos should learn Limonese Creole. As teacher Foster admits: "Now, incredible we have students that are not "Black" and they use the "Creole" in order for them to be "accepted" or to understand what is taking place and that depends on their friends (Foster, Sharon, interviewed by Grettel Vargas, November 1, 2011). On the other hand, $5 \%$ of the students believed that Limón Creole is not better than standard English and 5\% provided no answer.

In the same way, $90 \%$ of the adults considered that LC should be promoted between family members. Hence, this language should be documented in books and even in software as a way of reinforcing its pronunciation. Therefore, new generations should learn the difference between standard English and Limón Creole.

\section{Exhibit $\mathrm{N}^{\circ}{ }^{\circ} 10$ Limonese Creole as Part of Afro-Caribbean's Identity in Costa Rica Is it important to preserve the Limón Creole?}

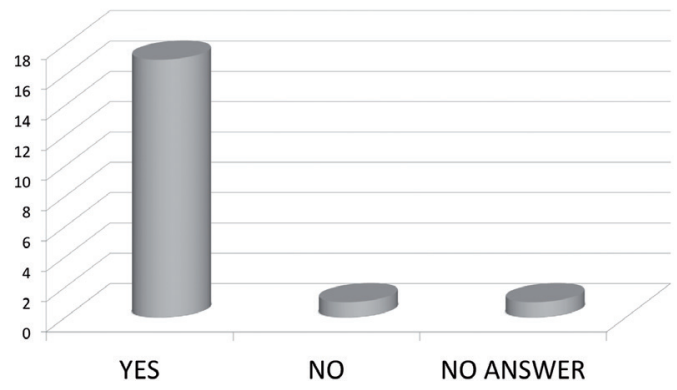

Source: Adults' Structured Interview--Open Ended Questions, September-October 2011.

In addition, religious institutions as well as schools should motivate young people to learn LC and it has to be included in the Costa Rica's Ministry of Education. Instead, $5 \%$ of the adults interviewed (1 person) affirms that this language is difficult to understand and another 5\% (1 individual) provided no answer.

In like manner, $74 \%$ of the students expressed they feel proud of the LC because it is part of their culture, it is a language that makes them unique around the country, it is something natural and some people really like it. However, others think that people who speak LC are disrespectful. 
Exhibit N. ${ }^{\circ} 11$

Are you Proud of Speaking Limón Creole?

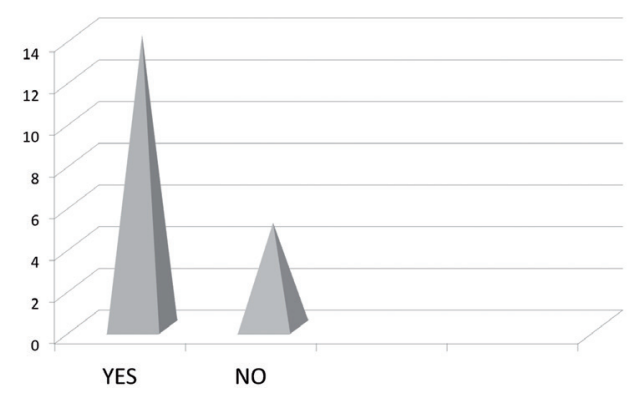

Source: Students' Structured Interview--Open Ended Questions, September 2011.

Similarly, 89\% of adults expressed they feel proud of LC because it is part of their identity, keeping this language means also to keep Afro Caribbean roots as an essential component of their grandparents' heritage. Whereas 11\% believed that they speak Limón Creole as well as Standard English. Indeed, another person considered that some people make fun of LC because they do not understand it.

\section{Exhibit N. ${ }^{\circ} 12$ \\ Are you Proud of Speaking Limón Creole?}

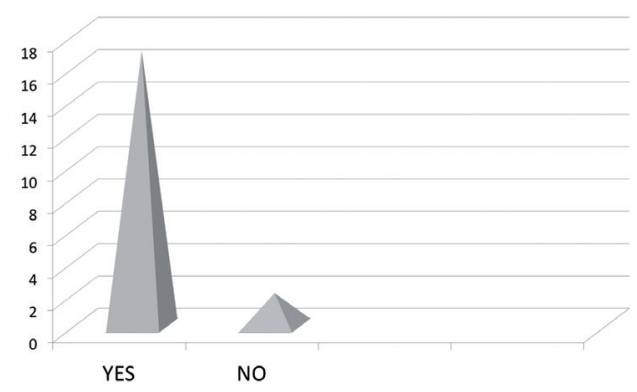

Source: Adults' Structured Interview--Open Ended Questions, September-October 2011.
Naturally, in response to the question: Are you multilingual? 21\% that represents 4 out of the 19 learners believed they are not multilingual, whereas $68 \%$ of them, which represents 13 out of the 19 pupils, considered they are multilingual. At the same time, $11 \%, 2$ out of 19 students judged they are bilinguals and stated that there is no difference between standard English and Limón Creole. In like manner, Mrs. Joycelyn Sawyers declares that: "I taught my daughter and the rest of people (in the school) that they are trilingual in Spanish, English and Limón Creole, but I would not take away the Standard English from Limón Creole (Sawyers, Joycelyn interviewed by Grettel Vargas, September 14, 2011).

\section{Exhibit N. ${ }^{\circ} 13$ Are you Multilingual?}

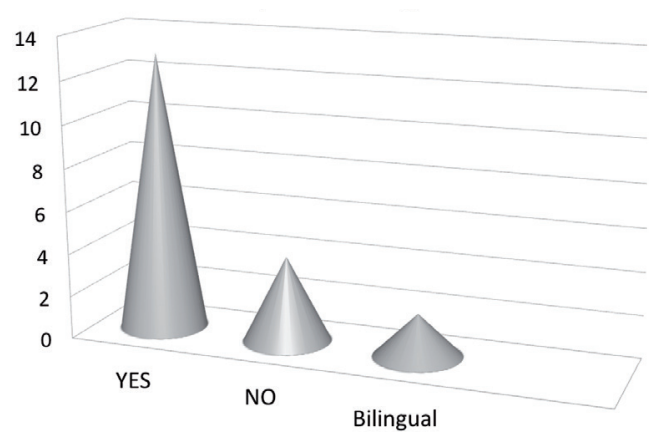

Source: Students' Structured Interview--Open Ended Questions, September 2011.

Instead, 59\% of older Afro-Caribbeans said that standard English and Limón Creole are basically the same, but they differ in the accent. $31 \%$ expressed that they do not consider themselves as multilingual and 10\% affirmed they are bilingual. 


\section{Exhibit $N .^{\circ} 14$}

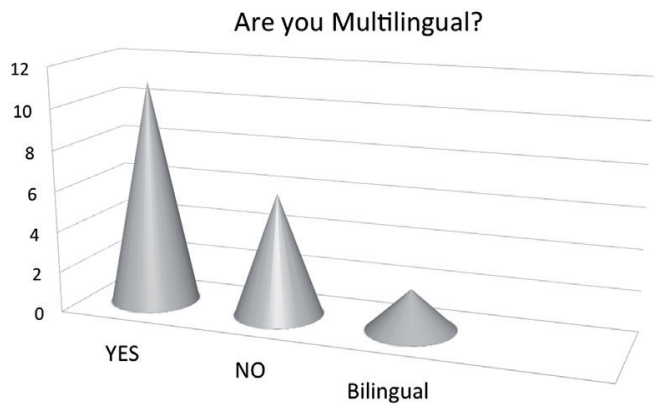

Source: Adults' Structured Interview--Open Ended Questions, September-October 2011.

On the other hand, the majority of the adults confirmed that when they were younger, they attended two schools: public Spanish school and English School. Some explained that it was forbidden to speak English and for that reason they were afraid of saying something in English, so they did it secretly. Nevertheless, $48 \%$ of the 19 adults who were interviewed confirmed they spoke Limón Creole when they attended classes in the Spanish school whereas $52 \%$ said they spoke Spanish in class.

\section{Exhibit N. ${ }^{\circ} 15$}

Dominant Language Used at School by adult Afro-Caribbean:

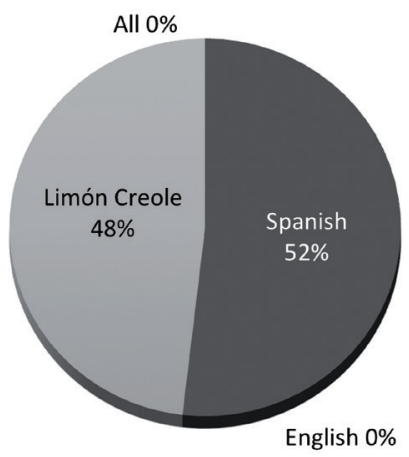

Source: Adults' Structured Interview--Open Ended Questions, September-October 2011.
Instead, regarding the dominant language students use at school, $40 \%$ affirmed it is Spanish, 24\% expressed it is LC and $36 \%$ confirmed they speak both.

\section{Exhibit N. ${ }^{\circ} 16$ \\ Dominant Language Used at School by young Afro-Caribbean:}

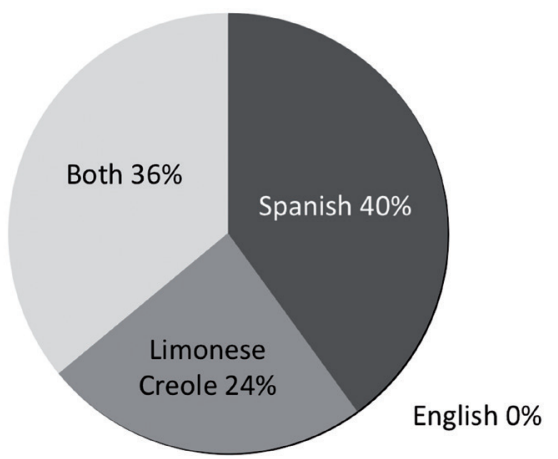

Source: Students' Structured Interview--Open Ended Questions, September 2011.

Thus, as teacher Foster emphasizes: "I think Limón Creole is spoken mainly by old people, if you notice in the market area, downtown or even at the bus stop you will find people who speak it, but among students definitely Spanish is the predominant language" (Foster, Sharon, interviewed by Grettel Vargas, November 1st, 2011). On the other hand, in response to the question Is it important to speak Limón Creole? $16 \%$ of young learners said that it is important to learn LC because it is part of the Afro-Caribbean culture and therefore it is necessary to preserve it. Nevertheless, $84 \%$ insisted that it is not necessary to speak LC to belong to the Afro-Caribbean culture since many Afro-descendents do not know how to speak LC. Other students affirmed that some young Afro-Caribbeans feel ashamed and discriminated because many people make fun of LC. Others 
said that the Afro-Caribbean culture is more than only language.

\section{Exhibit N. ${ }^{\circ} 17$}

Is it important to speak Limón Creole?

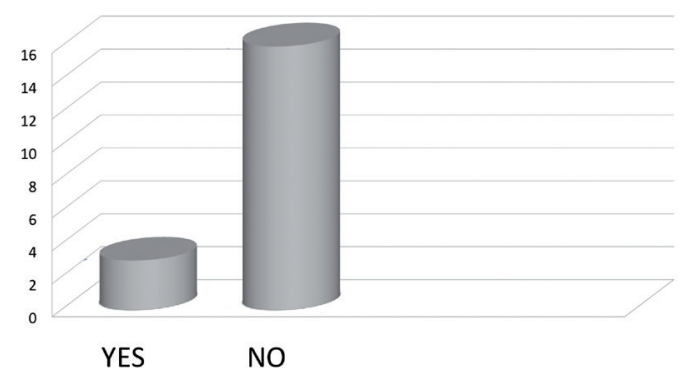

Source: Students' Structured Interview--Open Ended Questions, September 2011

Similarly, 32\% of older Afro-Caribbeans expressed that it is important to speak LC because that represents the Atlantic Zone of Costa Rica, it has more advantages than Spanish and also it unites old and young generations. On the other hand, $68 \%$ believed that speaking Limón Creole is more difficult for young people; for this reason, they do not speak LC well. Then, the majority of young Afrodescendents only speak Spanish. In addition, one person emphasized that Afro Caribbean people do not speak mekaytelyuw (negative way of describing LC).

\section{Exhibit N. ${ }^{\circ} 18$}

Is it important to speak Limón Creole?

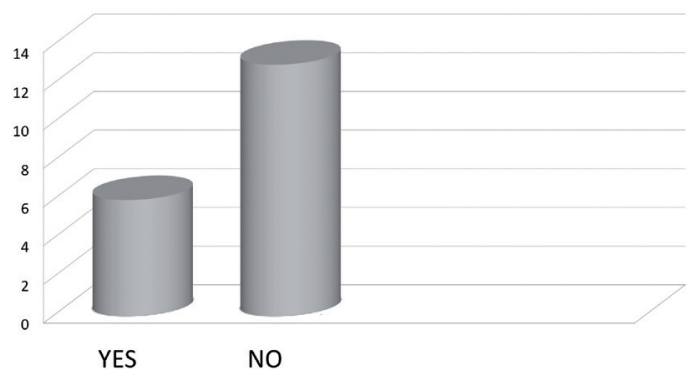

Source: Adults' Structured Interview--Open Ended Questions, September-October 2011.
Regarding the question What do you know about the Traditional English Schools in Limón? 79\% of the students said that in these schools Afrodescendent children learned English, some teachers came from Jamaica and the classes were offered in churches and houses. They also said that pupils in that time were not allowed to speak Spanish.

\section{Exhibit N. ${ }^{\circ} 19$ What do you know about the traditional English schools in Limón?}

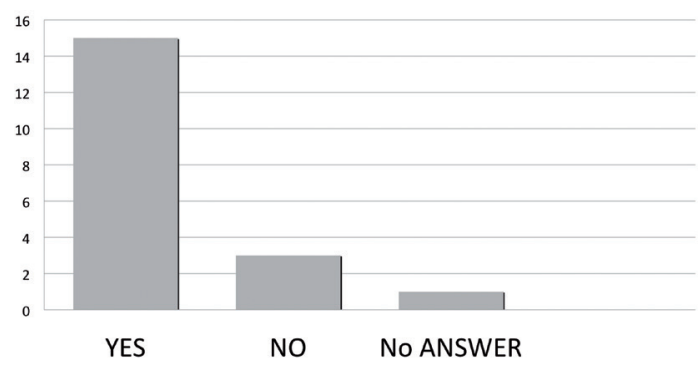

Source: Students' Structured Interview--Open Ended Questions, September 2011.

In like manner, $79 \%$ of adults responded to the question: Did you attend to traditional English schools in Limón? They affirmed that they indeed went to TES when they were younger. They explained that they attended to these schools that were located in churches and in some houses' porches. Among the subjects that these TES implemented in Limón were: pronunciation, grammar, spelling, reading, writing, arithmetic, science, geography, history, music, poetry, typing, craft, Christian education based on good manners and values such as respect, honesty and obedience, among others. Indeed, adults affirmed that some teachers came from Jamaica and they were really demanding and strict with the students. In addition, the children were not allowed to speak Spanish and 
in every "classroom" there were from twenty to twenty five students.

Exhibit N. ${ }^{\circ} 20$

Did you attend to traditional English schools in Limón?

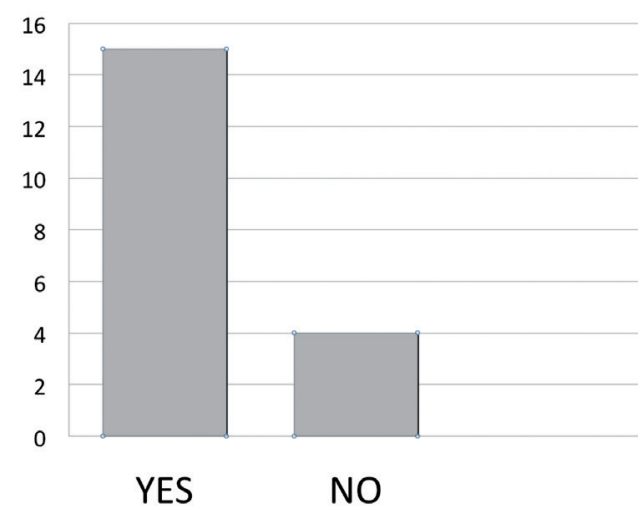

Source: Adults' Structured Interview--Open Ended Questions, September-October 2011.
These schools received children from four years to twelve years old or even fourteen years old. Certainly, one of the informants claimed that when she attended these schools she learned in a natural way without memorization. However, today students memorize everything in order to obtain a good grade in a test. On the other hand, $20 \%$ of the informants said that did not attend to the traditional English schools.

Exhibit N. ${ }^{\circ} 21$

Language Used by Students for Social Interactions:

\begin{tabular}{ccccc}
\hline & Spanish & English & LC & All \\
\hline With Afro-Caribbean & 1 & 4 & 5 & 11 \\
With No Afro-Caribbean & 13 & 3 & 1 & 5 \\
With friends & 6 & - & - & 14 \\
With family & 6 & - & 3 & 13 \\
At schoool & 12 & 8 & - & 8 \\
With tourist & 12 & 15 & 2 & 2 \\
TOTAL: & $44 \%$ & $26 \%$ & $10 \%$ & $47 \%$ \\
\hline
\end{tabular}

Source: Students' Structured Interview--Closed Questions, September 2011. 
Exhibit N.$^{\circ} 22$

Language Used by Adults for Social Interactions:

\begin{tabular}{lcccc}
\hline & Spanish & English & LC & All \\
\hline With Afro Caribbean & 5 & 1 & 10 & 9 \\
With No Afro Caribbean & 18 & 5 & 3 & - \\
With friends & 8 & - & 10 & 9 \\
With family & 3 & 6 & 12 & 7 \\
At work & 10 & 1 & 10 & 7 \\
With tourist & 5 & 18 & 1 & 1 \\
TOTAL: & $\mathbf{4 3 \%}$ & $\mathbf{2 7 \%}$ & $\mathbf{4 0 \%}$ & $\mathbf{2 9 \%}$ \\
\hline
\end{tabular}

Source: Adults' Structured Interview--Closed Questions, September-October 2011.

On the whole, a total of $44 \%$ of students asserted they use Spanish most of the time in different environments, circumstances and with different people. Instead, the young learners agreed they speak English mostly at school and with tourists (26\%). Nevertheless, only 10\% of the pupils affirmed they speak LC with Afro-Caribbean and family members, and $47 \%$ of them said they speak all of these languages: S, SE and LC.

In contrast, adult Afro-Caribbean said they are multilingual. They switched from Spanish (S), to standard English (SE) and to Limonese Creole (LC) easily, depending on the circumstances and setting. For example, at work they use Spanish and Lemonese Creole, with friends 40\% speak Lemonse Creole and 43\% Spanish. They prefer standard English for speaking with tourists. In brief, 43\% employ Spanish for social interactions, while 40\% Lemonese Creole, 27\% standard English and 29\% all of them.

\section{Conclusions}

The evidence suggests that older Afro-Caribbeans are multilingual in the sense that they exchange from Spanish, to standard English to Lemonese Creole and standard English in different situations and contexts, whereas students speak Spanish most of the time. Nevertheless, some learners expressed that they use Spanish, standard English and Limonse Creole in different moments. Taking these assertions, the researcher realized that young learners preferred to speak Spanish in informal situations. In fact, the majority of the young participants interviewed, that is $47 \%$, affirmed they can talk S, LC and SE depending on the context or with the people they are interacting. Only 10\% said they used LC and 26\% expressed they talked SE (at church and at school), and 44\% speak Spanish. 
To summarize, that was clear that older Afro-Caribbeans are multilingual. They expressed proudly that they are able to speak the three languages in special and concrete situations, environments and with different people. In addition, adults are identified with LC as part of their Afro-Caribbean culture and identity. However, they emphasized that also Spanish is part of their culture for being the country's official language and as Costa Ricans they must speak Spanish. On the other hand, some adults commented they experienced discrimination in Spanish schools when they were punished for speaking English. In spite of this situation, they were able to keep their ancestral languages, LC and SE, as a way to preserve their identity and culture. Some of them stated that the negative stereotypes as well as the interracial marriages have damaged the use of LC and SE at home. In fact, some expressed that some Afro-Caribbean parents only speak Spanish at home. Finally, adults said that this situation should change and the solution could be to promote the use of LC and SE at home.

In brief, there is a generation gap between students and adults, not only in terms of years but in terms of languages. Indeed, some learners considered Lemonese Creole a kind of broken language and the people who speak this language are disrespectful with others who cannot understand it. Students speak standard English at high school, but they showed some difficulties in expressing their ideas in a spontaneous way by using standard English.

In other words, through the observations, volunteer groups and interviews, the researcher concludes that young Afro-Caribbeans preferred to speak
Spanish in informal situations whereas they only speak SE in the classroom when their English teacher demands them to do it. In addition, young learners insisted that they are able to communicate in LC in any situation, but there was no evidence at least during the observations and focus groups that could support this assertion.

\section{Recommendations}

Accordingly, in order to promote the use of LC and SE among young Afro Caribbean generations in Limón, two recommendations could be considered. First, to promote a pilot plan in teaching ESL between the Methodist English School and St. Mark's school in order to teach English with the books TES used to teach. This could be done by incorporating the TES' curriculum to St. Mark's, mainly the books for learning grammar as a L2.

It is essential to clarify that through the development of this project, the researcher had the opportunity to interview Mrs. Ada Bryan Mc Claude who is a retired teacher who works at the Methodist English School. This school follows a traditional English school's curriculum. In fact, Mrs. Bryan is the school's principal as well as she is a teacher. During this interview, Mrs. Bryan explained that this school uses the books: New Royal Primer Part I and Part II as well as Nelson's West Indian Readers First Primer. Indeed, according to Mrs. Bryan, these books were employed by the teachers in the TES in Limón and basically the students from elementary school learned the alphabet, word building (syllabic division), sentence reading, spelling and pronunciation using 
those texts. In addition, the methodology the Methodist English School uses in teaching English is very similar to the methodology used in teaching Spanish, as a first language, using the book Paco y Lola. Mrs. Bryan affirms: "We try to let the children start parts in order to give them complete sentences. In English we start with syllables, just like in Spanish. Then, they go to words and then from words we take them from sentences and then they go to start reading" (Bryan Mc Claude, Ada, interviewed by Grettel Vargas, September 13, 2011). Then the researcher noticed during this interview that Mrs. Bryan asked a little girl from the elementary school in English to give the researcher her notebook and so this little girl was able to respond in English to what her teacher demanded; in fact, all the girl's notes were in English even the arithmetic exercises.

Next, Mrs. Bryan gave the researcher some copies of the books New Royal Primer Part I and Part II as well as Nelson's West Indian Readers First Primer. Then, the researcher realizes that essentially, each vowel and consonant lessons in these books is introduced by a picture and corresponding key-word. Below the key-word there are other words that rhyme with it. Each of these words are presented to the child in two forms: as a unit, and with the letters separated - in order to show that words are combinations of letters. On the whole, the lessons on the Primer books are almost entirely phonic with a few words introduced by "Look and Say" or "Word a Picture Matching".

During the development of this project, the researcher noticed that the correct use of grammar was highly emphasized through the English classes at St. Mark's high school; particularly for communicative activities such as speeches and role plays. Hence, the implementation of the New Primer books with its methodology based on phonics could improve the fluency and pronunciation among the students; mainly the students from the elementary school.

Finally, the second recommendation is to include as part of St. Mark's English curriculum, a literature class using Anancy's stories told in LC so the students could appreciate the oral traditions from their ancestral heritage. In like manner, this literature class could be included in the MEP's English curriculum in order to teach Afro-Caribbean tales and oral traditions in Limonese Creole for all Costa Rican students.

\section{Bibliography}

Herzfeld, Anita. Mekaytekyuw la Lengua Criolla. San José, Costa Rica: Editorial de la Universidad de Costa Rica, 2002. Print

Hernández Sampiere, Roberto, Carlos Fernández-Collado and Pilar Baptista Lucio. Metodología de la Investigación. México: McGraw-Hill Interamericana, 2006. Print.

IDESPO-UNICEF. Percepciones de los Costarricenses sobre la Población Afrodescendiente. San José, Costa Rica: UNICEF, 2010.

Isaacs, Harold R. Idols of the Tribe: Group Identity Politics and Change. Cambridge: Cambridge Publishing Company, 1995. Print

Le Compte, Margaret D. and Judith Preissle. Ethnography and Qualitative Design in Educational Research. AP: Academic Press, 2003.Print. 
Powell Bernard, Lorein. The Role of the State in the Destruction of a Symbolic Institution: The TES of Limón. Heredia, Costa Rica: Universidad Nacional, 2002. Print

Purcell, Trevor. Banana Fallout: Class, Color and Culture among West Indians in Costa Rica. Los Angeles: The Regents of the University of California, 1993. Print.

Riley, Philip. Language, Culture, and Identity. New York: Continuum, 2007. Print.

Sawyers Royal, Katherine and Franklin Perry. Minority Rights Group International Report Afro Central Americans: Rediscovering the African Heritage. England: British Library Cataloguing in Publication Data, 1996. Print.

Senior Angulo, Diana. Ciudadanía Afrocostarricense. El Gran Escenario Comprendido entre 1927-1963. San José, Costa Rica: Editorial Universidad Estatal a Distancia, Editorial Universidad de Costa Rica, 2011. Print.

\section{Recorded Interviews}

Writer Quince Duncan. August $12^{\text {th }}$, 2011.

Teacher Joycelyn Sawyers Royal. September $14^{\text {th }}, 2011$.

Teacher Ada Bryan Mc Claude. September $13^{\text {th }}, 2011$.

Teacher Sharon Foster. November $1^{\text {st }}$, 2011.

\section{Online Sources}

Bogdan, Robert C. and Sari Knopp Bilkqd. Qualitative Research for
Education. An Introduction to Theories and Models. http://www.francescoianni.com/Digital\%20Portfolio/ pdf\%20files/EDU7900\%20Qualitative\%20Research\%20for\%20Education.pdf. Web March 18 ${ }^{\text {th }}, 2010$.

Herzfeld, Anita. The Survival of a Creole Language in the Costa Rican Caribbean. Center of Latin American Studies, The University of Kansas http://www.continuinged. $\mathrm{ku} . \mathrm{edu} / \mathrm{sb} / \mathrm{presentations/herzfeld}$. html. Web June 15 th 2004.

McFall, B. and C. Beacham. Ideal Design Programming with Photoethnographic Data and Systems Analysis. Journal of Interior Design, 3. http://onlinelibrary.wiley.com/ doi/10.1111/j.1939-1668.2006. tb00529.x/abstract Web June $2^{\text {nd }}$, 2008.

Richard, Paul and Linda Elder. The Miniature Guide to Critical Thinking Concepts and Tools. http:// www.criticalthinking.org/files/Concepts_Tools.pdf. Web 2008.

Stocker, Karen. Citizenship, Wealth, and Whiteness in a Costa Rica High School. International Journal of Educational Policy, Research, and Practice, Volume 5, Number 4, Winter 2004-2005.Web.<http://eric.ed.gov/ ERIC WebPortal/search/detailmini. jsp?_95155>. Web December 2004.

Qualitative Research Methods: A Data Collector's Field Guide Module 1 Qualitative Research Methods Overview Family Health International. http://www.fhi.org/en/rh/pubs/ booksreports/qrm_datacoll.htm. Web September 10 $10^{\text {th }}, 2001$.

Video: Identidades: El Inglés Criollo. Canal 13. San José, Costa Rica. Universidad Estatal a Distancia (UNED). Documental, televisión, agosto 2010. 